NBER WORKING PAPER SERIES

CHARITABLE GIVING RESPONSES TO EDUCATION BUDGETS

\author{
Jonathan Meer \\ Hedieh Tajali \\ Working Paper 29331 \\ http://www.nber.org/papers/w29331 \\ NATIONAL BUREAU OF ECONOMIC RESEARCH \\ 1050 Massachusetts Avenue \\ Cambridge, MA 02138 \\ October 2021
}

We are grateful for assistance from Barbara Cvenic, Oliver Hurst-Hiller, Andi Muskaj, and Ali Rosen at Donorschoose.org. We received helpful comments from Daniel Hungerman, Benjamin Marx, Jennifer Mayo, and seminar participants at Duke University, the WZB Workshop on Recent Advances in the Economics of Philanthropy, the Cleveland Federal Reserve, Monash University, Southern Economic Association annual meeting, and the Western Economic Association annual meeting. The views expressed herein are those of the authors and do not necessarily reflect the views of the National Bureau of Economic Research.

NBER working papers are circulated for discussion and comment purposes. They have not been peer-reviewed or been subject to the review by the NBER Board of Directors that accompanies official NBER publications.

(C) 2021 by Jonathan Meer and Hedieh Tajali. All rights reserved. Short sections of text, not to exceed two paragraphs, may be quoted without explicit permission provided that full credit, including $(\odot$ notice, is given to the source. 
Charitable Giving Responses to Education Budgets

Jonathan Meer and Hedieh Tajali

NBER Working Paper No. 29331

October 2021

JEL No. D64,H41,H42,I22

\begin{abstract}
$\underline{\text { ABSTRACT }}$
Do changes in government spending affect voluntary contributions to those recipients? We examine how changes in K-12 education budgets impact donations to teachers using data from DonorsChoose.org, an online crowdfunding platform for public school teachers to raise money for their classrooms. Using a district-year panel and instruments to address the endogeneity of budgets, we find evidence for crowd-out of private giving, though the magnitudes are fairly small in this setting and do not offset a large proportion of a budget change. These results are driven by entirely teachers' posting of requests, illustrating the importance of considering the demand side of the charitable giving market.
\end{abstract}

Jonathan Meer

Department of Economics

TAMU 4228

College Station, TX 77843

and NBER

jmeer@econmail.tamu.edu

Hedieh Tajali

Department of Economics

TAMU 4228

College Station, TX 77843

htajali@tamu.edu 


\title{
Charitable Giving Responses to Education Budgets
}

\author{
Jonathan Meer* \\ Texas A\&M University Texas A\&M University \\ Working Paper \\ October 2021
}

\begin{abstract}
Do changes in government spending affect voluntary contributions to those recipients? We examine how changes in K-12 education budgets impact donations to teachers using data from DonorsChoose.org, an online crowdfunding platform for public school teachers to raise money for their classrooms. Using a district-year panel and instruments to address the endogeneity of budgets, we find evidence for crowd-out of private giving, though the magnitudes are fairly small in this setting and do not offset a large proportion of a budget change. These results are driven by entirely teachers' posting of requests, illustrating the importance of considering the demand side of the charitable giving market.
\end{abstract}

\section{Introduction}

The relationship between government funding of and private contributions to public goods is of key importance in understanding the nature of altruism and policy towards charitable giving (Roberts, 1984; Warr, 1982; Bergstrom et al., 1986; Okten and Weisbrod, 2000; Hungerman, 2005). ${ }^{1}$ Increased government spending may lead donors to give less, viewing taxation as a substitute for voluntary contributions - "classic" crowd-out - but charities may pull back on their fundraising efforts when receiving government funds - "indirect" crowd-out (Andreoni and Payne, 2003, 2011). Government grants can also have crowd-in effects, generally by serving as a signal of quality. ${ }^{2}$ Further, local preferences and conditions influence spending by the government, charitable giving by individuals, and fundraising decisions by charities. The same people who elect policymakers or vote on budgets are those who make donations, making it difficult to determine the causal relationship (Payne, 1998). If crowd-out is significant in magnitude and

\footnotetext{
${ }^{*}$ Author emails are jmeer@tamu.edu and htajali@tamu.edu. We are grateful for assistance from Barbara Cvenic, Oliver Hurst-Hiller, Andi Muskaj, and Ali Rosen at Donorschoose.org. We received helpful comments from Daniel Hungerman, Benjamin Marx, Jennifer Mayo, and seminar participants at Duke University, the WZB Workshop on Recent Advances in the Economics of Philanthropy, the Cleveland Federal Reserve, Monash University, Southern Economic Association annual meeting, and the Western Economic Association annual meeting.

${ }^{1}$ See De Wit and Bekkers (2017) for a recent meta-analysis of this literature.

${ }^{2}$ Vesterlund (2003) and Eckel et al. (2005) suggest that third-party contributions can have an endorsement effect that increases contributions. Heutel (2014) finds that government grants crowd in private donations, particularly for younger charities, positing that the grant serves as a signal of quality. Bekkers and De Wit (2020) find that directly providing information about government budget cuts can lead to more donations.
} 
primarily due to donors' responses, warm glow motivations may be less important (Andreoni, 1989, 1990; Ribar and Wilhelm, 2002).

In this paper, we examine how K-12 education budgets impact contributions to education, addressing the endogeneity issues inherent in estimating these relationships using instrumental variables. Recent evidence suggests that increases in education spending have positive effects on student outcomes, at least when that spending is reasonably well-targeted (Abott et al., 2020; Card and Payne, 2002; Jackson et al., 2015, 2018; Lee and Polachek, 2018); Jackson (2018) provides a recent review of the literature. The evidence is mixed on the response of private funding to changes in public education budgets. ${ }^{3}$ If voluntary contributions increase in response to budget cuts, then the effects of those cuts may be mitigated; however, depending on how those contributions are distributed, they may alleviate or exacerbate existing differences in resources.

In the paper most similar to ours, Andreoni and Payne (2011) decompose total crowd-out into classic and indirect components by estimating the impact of government grants on donations and fundraising separately, instrumenting with a set of variables for the political affiliation of the governor and congressional delegation. They also estimate the impact of fundraising on donations, instrumenting with variables for the financial health of the nonprofit organization. They find significant crowd-out, with a $\$ 1000$ grant reducing giving by over $\$ 700$, but this is entirely due to reduced fundraising effort; fundraising expenditures themselves are very effective at increasing donations.

We construct a district-year panel by linking data from Donorschoose.org, an online platform for public school teachers to post projects for prospective donors, to data from the Department of Education on school budgets. We examine the impact of changes in budgets on donations, as well as how teachers respond to those changes through their requests on the platform, allowing us to decompose crowd-out into its classic and indirect components. The primary concern for identification is that variation in school budgets and charitable contributions are both affected by unobserved economic factors, which can also impact teachers' willingness to post requests.

We first address this problem by including state- or county-by-year fixed effects in addition to school district effects to control for shocks affecting a particular area in a given year. But these specifications may not fully account for district-year shocks that affect budgets, postings, and contributions, leading to spurious correlation. We instrument for per-pupil spending using the timing of school finance reforms (Jackson et al., 2015; Bayer et al., 2020) and a shift-share variable measuring the district's exposure to state funding (Deming and Walters (2017) and Dinerstein et al. (2014) use similar instruments in the higher education context). Since it is possible that a local crisis impacts both teachers' requests and donors' willingness to give, we instrument for requests using previous years' request activity by neighboring districts. We also

\footnotetext{
${ }^{3}$ Jones (2015) finds a significant reduction in private education-related contributions when a state lottery whose proceeds fund education is introduced, and no evidence of changes in fundraising expenditures by educationrelated charities. Nelson and Gazley (2014) document the growth in school-supporting charities and find no correlation with changes in public financing of schools. Milton (2017) uses discontinuities in local tax referenda votes and finds no evidence of reductions in local private education contributions from increases in tax revenue. Grosskopf et al. (2020) examine the relationship between donations, fundraising, and enrollment (which generates government funding) for charter schools in Texas. They use measures of budget shortfalls and debt service obligations as instruments, as well as prior fundraising expenditures, and find evidence of crowd-out from exogenous fiscal shocks. In the private school sector, Hungerman et al. (2019) show that an increase in private school voucher revenue reduces the donations collected by Catholic churches.
} 
compare the effects on donations coming from the local area and elsewhere.

The DonorsChoose.org data have a number of advantages. Teachers' posts are easily linked to school districts and the sample size is large. Donations go to a specific project, which is fulfilled only if the requested threshold is met. There are no direct fundraising expenditures, which precludes us for measuring their effectiveness; however, charities' incentives to reduce administrative expenses lead to underreporting of these expenditures (Krishnan et al., 2006; Mayo, 2021).

Our instrumented results show that a 10 percent increase in per-pupil elementarysecondary spending leads to a 4.4 percentage point decrease in the likelihood that a teacher in that district posts a request in that fiscal year and around 40 percent decrease in the total amount requested by all teachers in that district. A 10 percent increase in per-pupil spending reduces the likelihood of any donation to a project by 4.1 percentage points and the total amount donated by 36 percent. Donations are very responsive to requests, with an 10 percent increase in total amount requested leading to about a 10 percent increase in donations, demonstrating the "power of the ask" in charitable giving (Andreoni and Rao, 2011; Andreoni et al., 2017; Meer and Rosen, 2011). The effectiveness of requests in this context suggests that teachers are leaving a significant amount of donations on the table. Taken together, a $\$ 1,000$ increase in per-pupil spending reduces donations by $\$ 628$; this is driven by a reduction in the amount requested of $\$ 1012$, which in turn reduces donations by $\$ 767$. While these magnitudes seem large, a $\$ 1,000$ increase in per-pupil spending dwarfs this reduction in donations for the average-sized district. We only examine one source of education-related charitable giving - DonorsChoose.org - so the overall effects may be larger.

This crowd-out is driven by the endogenous response of charities. Differentiating between classic and indirect crowd-out in this way demonstrates the importance of warm glow motivations in giving. We also contribute to the literature on crowdfunding in the context of charitable giving. ${ }^{4}$

\section{Data and Empirical Strategy}

\section{$2.1 \quad$ Data}

Information on project postings and donations come from DonorsChoose.org, an online platform for public school teachers to post projects and collect funding. Founded in 2000, more than 630,000 teachers have posted nearly 2 million projects for 40 million students on the site. The platform has attracted over $\$ 1$ billion in donations from 4.9 million donors. Figure 1 presents data on the growth of the organization.

Teachers select supplies from lists provided by vendors and writes a request that includes a discussion of student needs and the proposed use of the supply. Teachers also provide a photograph of their classroom. The request's page includes information about the school (such as its location and poverty level) and the project (such as its subject matter and the number of students reached). The request includes an itemized list of the materials requested, their price and quantity, and any additional charges. These projects are screened by the Donorschoose.org staff. Donors, whose gifts are tax-deductible, can browse, search, or filter projects. Figure 2

\footnotetext{
${ }^{4}$ Crowdfunding platforms have been used to study the impact of social distance (Meer and Rigbi, 2013), the value of completing projects (Wash, 2013), competition among causes (Meer, 2017), donor distaste for overhead costs (Meer, 2014), the role of social networks and pressure (Castillo et al., 2014, 2017), and other topics
} 
shows the page of a representative project; note that the layout of the web page has changed several times over the history of the organization.

If a project reaches its goal, DonorsChoose.org purchases the materials and ships them directly to the teacher. If the project expires prior to being funded, donors have the option to have the funds returned to their account to select another project or to have DonorsChoose.org select a project for them. Projects that do not reach their goal generally expire after four months.

Data on projects, including National Center for Education Statistics ID number for the school, is available beginning in 2002. These consist of $1,715,764$ projects posted by the end of 2018, of which $68.5 \%$ met their goal. The mean project amount requested (in 2017 dollars) is $\$ 791$ with a median of $\$ 484$. About 32 percent of projects request classroom supplies, with 18 percent requesting books and 30 percent requesting some form of technology. 83 percent of projects posted and 82 percent of dollars requested were from low-income schools, as defined by the percent qualifying for free and reduced-price lunch.

We aggregate the project data to the fiscal-year level, matching projects' posted dates to state fiscal years. We classify the amount requested to the fiscal year in which the project was posted, and the amount donated to the fiscal years in which those projects were funded. ${ }^{5}$

We link this to the Department of Education Common Core of Data (CCD), which covers the 1995 to 2018 school years. The sample begins with 409,108 observations. We exclude districts with fewer than 50 students enrolled, as is standard in the literature (Cellini et al., 2010) and drop those with missing ID numbers, leaving 380,090 observations. ${ }^{6}$ Dropping observations with missing financial information leaves a final sample of 352,450 district-year observations representing 17,546 districts. 21.7 percent of observations have at least one project posted (31 percent from the start of the DonorsChoose.org data in 2003); 81.2 percent of districts ever have a project posted. The data represent 1,572,790 individual projects are posted by 848,258 teachers, with 8,407,053 donations, totaling 688.6 million dollars. Conditional on at least one project being posted in a district-year, the mean number of projects is 20.6, posted by 11.1 teachers. The mean amount raised in a district-year, conditional on any donations, is $\$ 9,600.03$, with a median of $\$ 1,436.70$. Nominal dollar amounts are adjusted to 2017 dollars. Table 1 reports summary statistics for the district-year observations. Panel A shows summary statistics for district characteristics and financial information from our final sample. In Panel B, we present descriptive statistics for variables related to project posting from DonorChoose.org conditional on any project posted. We provide information for donation variables conditional on any contribution received in Panel C. ${ }^{7}$

We construct per-pupil measures of revenue and expenditure using the CCD. ${ }^{8}$ Total

\footnotetext{
${ }^{5}$ We consider all donations, including those for projects that were not fully funded, as a measure of donor intent. The results are nearly identical when examining donations to projects that are entirely funded.

${ }^{6}$ As recommended by the National Center for Education statistics (NCES) Common Core of Data documentation (Cornman et al. (2020)), we keep those school districts with records matched to the Local Education Agency universe file.

${ }^{7}$ Beginning in 2006, the Common Core of Data asks districts to report "gifts of cash or securities from private individuals or organizations." Using this outcome instead of the Donorschoose.org data, we find evidence of crowd-out from increased K-12 spending, though the estimates are noisy. However, the lack of data on fundraising expenditures needed to compare classic and indirect crowd-out make this variable ill-suited for our purposes.

${ }^{8} \mathrm{~A}$ small number of observations have extreme values well outside of a reasonable range for per-pupil spending. Winsorizing at the 99.9th percentile (353 observations) - that is, setting those values equal to that of the 99.9th percentile level - makes no difference to the results.
} 
expenditures includes elementary-secondary expenditures (83.9 percent of the total), capital outlay expenditures (9.9 percent), payments to state or local governments, payments to different school systems, and interest paid. We focus on elementary-secondary expenditures because those expenditures directly affect operating the schools in the given school year. They include items such as salaries for school personnel, benefits, student transportation, school books, and materials. ${ }^{9}$ Figure 3 shows per-pupil total expenditures, per-pupil elementary-secondary spending, and per-pupil capital expenditures in school districts between 1995 and 2018. We also extract the number of teachers in the district, the share of children living in poverty, and enrollment shares by race, ${ }^{10}$ together these variables are available for 268,854 observations.

\subsection{Empirical Approach}

School spending is not randomly assigned. It is likely to be correlated with permanent and transitory economic conditions, as well as the underlying prosociality of a district's residents, which also impact charitable giving.

We include district fixed effects and school district demographics in our specifications to control for the factors that may confound the relationship between spending and donations. Year effects account for macroeconomic conditions that affect the entire country, but these do not account for time-varying shocks that affect only the region. For example, a localized recession could lead to both cuts in school spending and a reduction in donors' ability to make gifts. We include state-by-year fixed effects to capture this variation. Shocks at a more local level could still leave spurious correlation; we also estimate specifications including county-byyear fixed effects. But this approach does not fully account for time-specific factors within a district that could be driving the relationship between spending, fundraising requests, and donations. Below, we describe the set of instrumental variables we use to address this issue.

An advantage of the DonorsChoose.org data is that we can observe the demand for donations (as measured by projects posted by teachers) as well as the equilibrium outcome (projects funded and amounts donated). It is tempting to think of the amount donated as the supply of donations, but it is a function of both donors' intent and their opportunities - if there are no projects posted in a particular district, donors cannot give through the platform. By examining these outcomes separately, we can better determine whether teachers are responding to budget pressures separately from donors' behavior.

We focus on elementary-secondary expenditures, which include items like salaries for school personnel, benefits, student transportation, school books, and materials. Capital spending, which tends to be longer-run, is less likely to affect teachers' posting and donors' giving; we examine these expenditures separately.

Of course, DonorsChoose.org is only one avenue for private contributions to education. Parent-teacher organizations raise significant amounts of money (Cope, 2019) and may serve as another conduit for funds. But the DonorsChoose.org platform, which allows us to examine teacher demand for financing and allows for donations from people not necessarily connected to the district, provides significant advantages in examining this question.

\footnotetext{
${ }^{9}$ Teacher salary expenditures make up around 41 percent of total elementary-secondary spending.

${ }^{10}$ We obtain information on estimated population ages 5-17 in poverty from the U.S. Census Bureau's Small Area Income and Poverty Estimates program (SAIPE), and enrollment by race from Rutgers University School Funding Fairness Database (Baker et al. (2016)).
} 


\subsection{Specification}

The Tobit is often used when there are many observations with outcomes equal to zero. However, this model suffers from tractability problems in the presence of fixed effects, is likely not appropriate when zeroes arise from corner solutions rather than true data censoring, and constrains the marginal effects on the extensive and intensive margins to be proportional to each other. This last issue is particularly problematic when considering the impact of, say, per-pupil spending, which may have different effects on the likelihood of a request receiving a donation and the total amount received.

We use a single-hurdle model to first examine whether any project is posted (or receives a donation) in a given district-year and then separately estimate the effects on the intensive margin (the number of projects posted, the amount requested, or the amount received in donations). We then combine the results to find marginal effects on the unconditional means. ${ }^{11}$

In the first stage, we examine whether any projects have been posted or if any donation is made, as shown in equation 1, which we estimate with a linear fixed effects model.

$$
P\left(Y_{s d t}=1\right)=\alpha+\beta \cdot \operatorname{Exp}_{d t}+\delta \cdot X_{d t}+\gamma_{d}+\mu_{t}+\eta_{s t}+\epsilon_{s d t}
$$

Where d, s, and t index districts, states, and (fiscal) years, respectively. $\operatorname{Exp}_{d t}$ is the log of per-pupil expenditures in district $d$ and year $t$. We also include the share of children ages 5 to 17 in poverty, the log of number of teachers in a district-year, and enrollment shares by race in $X_{d t} \cdot \gamma_{d}, \mu_{t}$, and $\eta_{s t}$ are district fixed effects, year fixed effects, and state-year (or county-year) fixed effects, respectively. Standard errors are clustered at the district level.

The second stage estimates effects on the intensive margin. The outcomes of interest for this specification, in Equation 2, are the log of the number of posted projects, log of the amount requested, and the log of the amount donated. We estimate this equation using a linear fixed effects model only on observations for which there is a nonzero outcome.

$$
\log Y_{s d t}=\alpha+\theta \cdot \operatorname{Exp}_{d t}+\delta \cdot X_{d t}+\gamma_{d}+\mu_{t}+\eta_{s t}+\epsilon_{s d t} \text { if } Y>0
$$

Given the equations 1 and 2 , the coefficients of the interest are $\beta$ and $\theta$ (respectively). The second stage effect cannot be taken as causal, though, because it reflects both a compositional change from the change in the sample due to the extensive margin effect as well as a behavioral effect on those whose extensive margin behavior does not change. That is, it consists of both a treatment effect and a change in the composition of the sample. However, these coefficients can be be combined to find the marginal effect on the unconditional mean:

$$
\frac{d P\left(Y_{d t}>0\right)}{d \log \operatorname{Exp}_{d t}} \times E\left[\log Y_{d t} \mid Y_{d t}>0\right]+P\left(Y_{d t}>0\right) \times \frac{d E\left[\log Y_{d t} \mid Y_{d t}>0\right]}{d \log E x p_{d t}}
$$

For the relationship between the amount requested and the amount given, we estimate specifications conditional on a request. No donations can be given through DonorsChoose.org without a request. As such, there are no observations for which there are positive donations but no requests.

$$
\text { Log Donations }_{s d t}=\alpha+\theta \cdot \operatorname{LogRequests_{sdt}}+\delta \cdot X_{d t}+\gamma_{d}+\mu_{t}+\eta_{s t}+\epsilon_{s d t} \text { if Requests }>0
$$

\footnotetext{
${ }^{11}$ See Huck and Rasul (2011) and Meer (2011) for further discussion on the use of this approach for charitable giving estimates.
} 


\subsection{Instrumental Variables}

These specifications include county-by-year fixed effects, district fixed effects, and district-level demographic variables to account for local conditions and factors that impact both giving and school expenditures. But it is possible that within a county, a school district's economic fortunes were trending downwards in a way that is not captured by our other controls, leading to both lower expenditure and reduced giving by its residents. Or a shock to the district may lead to spurious correlation: for example, a natural disaster could lead to greater giving and changes in government spending. Districts with lower levels of spending may be more likely to hire new teachers, who are more likely to be familiar with platforms like DonorsChoose.org.

It is difficult to rule out all such stories. But the use of instrumental variables which affect expenditures but are uncorrelated with district-specific shocks can assuage these concerns. We use versions of two sets of instrumental variables that have been used recently in the economics of education literature to instrument for per-pupil spending. ${ }^{12}$

First, we adapt the school finance reform instruments used in Jackson et al. (2015) and Bayer et al. (2020), who argue that judicially-imposed reforms are an exogenous source of variations, and which increase per-pupil spending by more in low-income districts than higherincome ones. ${ }^{13}$ The early reforms they study, beginning in the 1970 s, are too far in the past to have appreciable impacts in our sample, yielding a weak first stage and imprecise and implausible estimates. We limited the sample to the seven reforms since 1995 (Vermont, Ohio, Michigan, Idaho, New York, South Carolina, and Oregon), interacted with base-year district spending quartile, and replicated those findings. Figure 4 shows an event study graph of the impact of these reforms on per-pupil expenditures in a regression that includes year and district fixed effects. The F-statistics for the first stages are 33 and 44 on the extensive margin for the specifications without and with additional controls, respectively, and 22 and 25 on the intensive margin.

We also follow Deming and Walters (2017), who use a shift-share instrument for higher education expenditures, interacting an institution's appropriations revenue share in an initial year with the current year's total state appropriations (on a per-college-aged-population basis). In a similar vein, we interact a district's share of its revenues coming from state appropriations in the first year it appears in our sample with current state appropriations divided by the number of children between the ages of 5 and 18, as shown below.

$$
Z_{d, t}=\left(\frac{\text { District }^{\prime} s \text { State } \text { Revenue }_{d, t=1}}{\text { District's Total Revenue }_{d, t=1}}\right) \times\left(\frac{\text { State Revenue }_{s(d), t}}{\text { Pop ages } 5-18_{s(d), t}}\right)
$$

If state appropriations increase, districts that are more reliant on state revenue in the baseline year are more likely to have revenue increases. But this measure will not be related to changes in the district's circumstances, which are more likely to be correlated with unobserved

\footnotetext{
${ }^{12}$ We considered using discontinuities around school budget votes as a source of identifying variation for changes in charitable giving, using data from New Jersey and New York. We found little impact on per-pupil spending and the results were sensitive to specification. We also follow Baron (2019), who finds that operational referenda in Wisconsin increase per-pupil expenditures, replicating his finding. However, the relatively small sample size of DonorsChoose.org projects posted in Wisconsin in the relevant time periods yields noisy estimates.

${ }^{13}$ We also replicated the results in Brunner et al. (2021), which use the construction of wind farms to proxy for increases in revenues. However, as Brunner et al. (2021) explain, these revenues are more likely to be used for capital expenditures (and, in some cases, are required to be used as such). As they did, we found little first-stage effect on elementary-secondary expenditures, making this approach unsuitable for our purposes.
} 
factors that also impact project postings and donations. Since increases in state-level spending on education are expected to increase spending in districts that are more reliant on state aid, we expect this measure to have a positive coefficient in the first stage estimates. As shown in Columns 1 and 3 of Tables 5 and 6 - which also include the school finance reform indicators it does, in both the extensive and intensive margins, and is precisely estimated.

Using these instruments in our specifications for donations and requests comes at a cost. Both are determined at the state-year level. The school finance reform variables are a function of a district-specific factor (the district's resource quartile) multiplied by a state-year function. The shift-share instrument is similarly composed of a district-level factor (reliance on state revenue in the baseline year) multiplied by a state-year function. As such, including state- or county-by-year effects in the instrumented specifications leaves little identifying variation. ${ }^{14}$

When estimating the effect of the amount requested on the amount donated, we instrument using the amount and number of projects posted by neighboring school districts. ${ }^{15}$ We use school district boundary information from the Education Demographic and Geographic Estimates (EDGE) Program and determine the neighboring districts based on the 1995 geographic estimates (Files; Geverdt, 2018). ${ }^{16}$ For these specifications, we can include state-by-year or county-by-year fixed effects. As seen in Table 7, these instruments tend to be statistically significant; in practice, the relationship between amount requested and amount donated is similar with and without instrumental variables. The set of instrumental variables used does not greatly affect the estimates.

As a further check, we examine the relationship between a given year's amount requested and the previous and following year's amount given. If this latter relationship is strong, it would suggest that unobserved trends are driving teachers' posting behavior and donors' giving. In a specification with district and county-by-year fixed effects, previous year's giving has a small impact on this year's amount requested, with an elasticity of 0.051 (s.e. $=0.01$ ); the following year's giving has no effect, with a coefficient of 0.0025 (s.e. $=0.016$ ).

\section{Results}

\subsection{Baseline Specifications}

\subsubsection{Teacher Postings}

We begin with the demand side - that is, postings by teachers. Changes in expenditures are generally more salient to teachers than to parents. Further, teachers can post a request irrespective of the desire to donate. This response, therefore, gives a measure of the need perceived by teachers. ${ }^{17}$

\footnotetext{
${ }^{14}$ Recent work by Goldsmith-Pinkham et al. (2020) indicates that the shift-share approach is equivalent to using the initial shares as instruments, weighting by the overall shift over time. While we cannot verify that this exclusion restriction holds, the baseline year for most districts is eight years before the availability of DonorsChoose.org; as such, the shares are more likely to reflect these initial conditions and be excludable from the second stage.

${ }^{15}$ We sum these variables among all neighboring districts, adding 1 before taking logs.

${ }^{16}$ There are some errors in these files, often due to districts merging or splitting, but they are relatively infrequent.

${ }^{17}$ Of course, we cannot reject the possibility that teachers are responding to a stated desire to give by potential donors; for example, a parent may suggest to his or her child's teacher that the teacher post a request to allow for tax-deductible directed giving to that classroom. Note that donations can come from anywhere. Meer (2017) shows that general geographic proximity does have a meaningful effect on donor preferences, but that many
} 
Panel A of Table 2 shows the impact of per-pupil elementary-secondary expenditures on the likelihood that any project is posted in the district in a given year, including state-by-year and district fixed effects. Column (1) shows that a 10 percent increase in those expenditures leads to a 0.6 percentage point decrease in the likelihood of a posted project (standard error $=$ 0.075 percentage points).

Adding county-by-year fixed effects in Column (2), to account for more local economic and political shocks in a given year that could impact both budgets and giving, reduces this effect to -0.47 percentage points for a 10 percent change in expenditures. Columns (3) and (4) add a set of control variables for the share of students in poverty, the log of the number of teachers, and enrollment shares by race to the specifications in Columns (1) and (2), respectively. This reduces the sample somewhat due to missing data. In the specification with state-by-year effects, a 10 percent increase in the per-pupil elementary-secondary budget reduces the likelihood of a posting by 0.53 percentage points (s.e. $=0.11$ ), while with county-by-year effects, the reduction is 0.38 percentage points (s.e. $=0.13) .{ }^{18}$

Panel B examines the intensive margin of the number of dollars requested by teachers, conditional on a project being posted. Increased budgets are associated with reduced posting on the intensive margin, though these estimates are imprecise and cannot be interpreted causally since they consist of both a treatment effect and a change in the composition of the sample. But in Panel C, we combine these effects. Combining the negative effects on the extensive margin and intensive margins, we find an elasticity of -0.31 (s.e. $=0.094$ ) for the specification in Column (4). We conclude, therefore, that teachers are responsive to changes in educational budgets; they reduce their efforts to raise external funds in the face of higher budgets. These results are similar in spirit with those in Andreoni and Payne (2003) and Andreoni and Payne (2011), who find a significant reduction in fundraising expenditures in response to government grants.

\subsubsection{Donations}

In Table 3, we turn to combined effect of teacher requests and donors' contributions. Panel A shows the effects on the likelihood that any donations are made. Column (4), which includes both controls and county-by-year effects, shows that a 10 percent increase in expenditures leads to a 0.27 percentage point decrease in the likelihood of a donation (s.e. $=0.13$ percentage points).

In Panel B shows the intensive margin effect on the amount donated. The intensive margin effects are close to zero and imprecisely estimated. Combining the effects in Panel E yields an elasticity of -0.20 (s.e. $=0.091$ ) in Column (4).

The similarity of this elasticity to that of the amount requested suggests that the crowding out we observe is primarily due to teachers' reduced posting of projects. This finding is consonant with Andreoni and Payne (2011), who find that lower fundraising expenditures lead to the majority of the observed fall in charitable giving in response to a government grant.

\footnotetext{
donations are given to schools outside of the area in which the donor lives.

${ }^{18}$ The change between the first two columns and the second two is driven by the inclusion of the controls. Estimating the more parsimonious specification on the limited sample in Columns (3) and (4) yields results similar to those in (1) and (2), respectively.
} 


\subsubsection{Fundraising Effectiveness}

Finally, we estimate the impact of requests on donations. This specification differs from those above since donations can only be made in response to a request. Table 4 show similar results across all the columns, with a 10 percent increase in the amount requested associated with a roughly 9 percent increase in donations. While this is not directly comparable to the effect of fundraising expenditures in other work, it is line with the findings that charities are not revenue maximizers - that is, it appears that teachers could raise more funds by posting more projects.

\subsubsection{Estimates of Classic and Indirect Crowd-Out}

These estimates can be combined to decompose the total change in crowd-out into its classic and indirect components. Using the specifications that include controls and county-by-year effects, a $\$ 1,000$ increase in per-pupil expenditures yields a total decrease in donations of $\$ 35$, measured at the means of annual district-level expenditures and donations. The amount requested declines by $\$ 78$, yielding a reduction in donations of $\$ 49$. Indirect crowd-out therefore accounts for the entirety of the reduction in donations, with a small but statistically insignificant amount of crowd-in as the direct effect of increased K-12 spending.

Though the elasticities that generate them are precisely estimated, these values are even smaller in magnitude than they appear. The average district-year observation has an enrollment of 3255 students, meaning that a $\$ 1,000$ increase in per-pupil expenditures, taken as a whole, dwarfs the reduction in donations. But these estimates do not account for potential endogeneity issues, to which we turn in the next section.

\subsection{Instrumented Specifications}

\subsubsection{Teacher Postings}

We begin again with the demand side, examining the effect on teacher postings. The instrumented specifications include year and district fixed effects, since most of the variation in the instruments is at the state-year level. The effects on the extensive margin are much larger; Table 5 shows that a 10 percent increase in per-pupil elementary-secondary expenditures reduces the likelihood of a project being posted by 4 percentage points. Panel B shows that the effects on the intensive margin are also negative, with a coefficient of -0.94 (s.e. $=0.23$ ) - again, note that one cannot draw causal conclusions from these estimates. The inclusion of controls does not change the coefficients very much. Combining the estimates yields an unconditional elasticity of -4.0 (s.e. $=0.30$ ). This estimate appears quite large, perhaps implausibly so, but it compares per-pupil expenditures to overall donations; we benchmark the estimates below for a more clear interpretation.

\subsubsection{Donations}

Turning to the amount donated, reported in Table 6, we once again see that the effects of changing K-12 budgets are similar to the effects on postings. The impact of a 10 percent increase in per-pupil elementary-secondary spending on the extensive margin is about -4 percentage points (s.e. $=0.3$ percentage points). On the intensive margin, the coefficient is -1.5 (s.e. $=$ 0.29 ). Combining the effects yields an estimated elasticity of -3.6 (s.e. $=0.29$ ). 


\subsubsection{Fundraising Effectiveness}

Since there is within state-year (and county-year) variation in the instruments used for the amount requested, we report specifications that include those additional fixed effects in Table 7. In practice, the coefficients do not change much when these finer controls are included. Much like the uninstrumented estimates, the elasticity of donations with respect to requests is close to 1 , suggesting that teachers could raise more money by posting more projects.

\subsubsection{Estimates of Classic and Indirect Crowd-Out}

Using the instrumented results, we decompose total crowd-out into the classic and indirect effects. A $\$ 1,000$ increase in per-pupil expenditures yields a total decrease in donations of $\$ 628$, measured at the means of annual district-level expenditures and donations. The amount requested declines by $\$ 1012$, yielding a reduction in donations of $\$ 767$. As above, indirect crowdout accounts for the entirety of the reduction in donations, with potentially a small amount of crowd-in from increased spending.

The magnitudes here are much larger than those in Section 3.1.4, but still small compared to the total expenditure change for the average district. A $\$ 1,000$ increase in per-pupil elementary-secondary expenditures is about $\$ 3.2$ million at the mean, compared to a reduction of $\$ 628$ in donations.

\subsection{Additional Results}

\subsubsection{Donor Location}

Examining the response of local and non-local donors to changes in changes in elementarysecondary expenditures provides suggestive evidence on the degree to which shocks to local preferences that affect both giving behavior and K-12 funding are a concern. About 85 percent of the dollars donated are associated with observations that have the donor's state available. ${ }^{19}$ In-state donors are somewhat more responsive to changes in expenditures than out-of-state donors, with an instrumented elasticity of $-3.3($ s.e. $=0.25)$ as compared to $-2.8($ s.e. $=0.26)$.

However, this finding should not be taken as definitive. Expenditures are likely more salient to locals, but states are fairly large geographic areas. And ultimately, given the evidence that changes to teachers' posting behavior drive the results - and the small role that classic crowd out plays - this is not surprising.

\section{Discussion \& Conclusion}

We examine how K-12 education budgets impact private giving to education. Using rich data from DonorsChoose.org, we show that teachers respond to changes in school expenditures by reducing both the likelihood of making a request for funds and the overall amount requested. This, in turn, reduces contributions.

We show that private contributions can counteract changes in government spending, though the magnitudes we find are small. But our primary contribution is shedding light on the nature of altruism. If donors are driven by pure altruism, that is, a simple desire to see public goods provided irrespective of their own actions, theory suggests that they will reduce their

\footnotetext{
${ }^{19}$ ZIP codes are available for far fewer observations, so we focus on state.
} 
donations in the face of government spending. Taken on their own, the effect of expenditures on donations would suggest that this is the case. But by examining the impact of expenditures on teachers' requests, and of requests on donations themselves, we show that this effect is entirely driven by endogenous responses on the part of the teachers. This shows the importance of considering the demand side of the charitable giving and nonprofits' objective functions.

\section{References}

Abott, C., Kogan, V., Lavertu, S., and Peskowitz, Z. (2020). School District Operational Spending and Student Outcomes: Evidence from Tax Elections in Seven States. Journal of Public Economics, 183:104142.

Andreoni, J. (1989). Giving with Impure Altruism: Applications to Charity and Ricardian Equivalence. Journal of Political Economy, 97(6):1447-1458.

Andreoni, J. (1990). Impure Altruism and Donations to Public Goods: A Theory of Warm-Glow Giving. The Economic Journal, 100(401):464-477.

Andreoni, J. and Payne, A. A. (2003). Do Government Grants to Private Charities Crowd Out Giving or Fund-raising? American Economic Review, 93(3):792-812.

Andreoni, J. and Payne, A. A. (2011). Is Crowding Out Due Entirely to Fundraising? Evidence from a Panel of Charities. Journal of Public Economics, 95(5):334-343.

Andreoni, J. and Rao, J. M. (2011). The Power of Asking: How Communication Affects Selfishness, Empathy, and Altruism. Journal of Public Economics, 95(7):513-520.

Andreoni, J., Rao, J. M., and Trachtman, H. (2017). Avoiding the Ask: A Field Experiment on Altruism, Empathy, and Charitable Giving. Journal of Political Economy, 125(3):625-653.

Baker, B. D., Srikanth, A., and Weber, M. A. (2016). Rutgers Graduate School of Education/Education Law Center: School Funding Fairness Data System. Retrieved from: http://www.schoolfundingfairness.org/data-download.

Baron, E. J. (2019). School Spending and Student Outcomes: Evidence from Revenue Limit Elections in Wisconsin. Available at SSRN 3430766.

Bayer, P., Blair, P. Q., and Whaley, K. (2020). The Impact of School Finance Reforms on Local Tax Revenues. AEA Papers and Proceedings, 110:416-18.

Bekkers, R. and De Wit, A. (2020). Can Charitable Donations Compensate for a Reduction in Government Funding? The Role of Information. Public Administration Review, 80(2):294304.

Bergstrom, T., Blume, L., and Varian, H. (1986). On the Private Provision of Public Goods. Journal of Public Economics, 29(1):25-49.

Brunner, E., Hoen, B., and Hyman, J. (2021). School District Revenue Shocks, Resource Allocations, and Student Achievement: Evidence from the Universe of US Wind Energy Installations. (EdWorkingPaper: 21-352). Retrieved from Annenberg Institute at Brown University: https://doi.org/10.26300/ssze-jq2. 
Card, D. and Payne, A. A. (2002). School Finance Reform, the Distribution of School Spending, and the Distribution of Student Test Scores. Journal of Public Economics, 83(1):49-82.

Castillo, M., Petrie, R., and Wardell, C. (2014). Fundraising Through Online Social Networks: A Field Experiment on Peer-to-Peer Solicitation. Journal of Public Economics, 114:29 - 35.

Castillo, M., Petrie, R., and Wardell, C. (2017). Friends Asking Friends for Charity:The Importance of Gifts and Audience. Available at SSRN 2658294.

Cellini, S. R., Ferreira, F., and Rothstein, J. (2010). The Value of School Facility Investments: Evidence from a Dynamic Regression Discontinuity Design. The Quarterly Journal of Economics, 125(1):215-261.

Cope, S. (2019). The Power of a Wealthy PTA. The Atlantic. https://www.theatlantic.com/education/archive/2019/11/pta-fundraising-schools/601435/.

Cornman, S., Ampadu, O., and Hanak, K. (2020). Documentation for the NCES School District Finance Survey (F-33), School Year 2016-17 (Fiscal Year 2017), Provisional File Version 1a (NCES 2020-304). National Center for Education Statistics, Institute of Education Sciences, U.S. Department of Education. Washington, DC. Retrieved [date] from https://nces.ed.gov/pubsearch.

De Wit, A. and Bekkers, R. (2017). Government Support and Charitable Donations: A MetaAnalysis of the Crowding-out Hypothesis. Journal of Public Administration Research and Theory, 27(2):301-319.

Deming, D. J. and Walters, C. R. (2017). The Impact of Price Caps and Spending Cuts on U.S. Postsecondary Attainment. Working Paper 23736, National Bureau of Economic Research.

Dinerstein, M. F., Hoxby, C. M., Meer, J., and Villanueva, P. (2014). 9.Did the Fiscal Stimulus Work for Universities? How the Financial Crisis and Great Recession Affected Higher Education, edited by Jeffrey R. Brown and Caroline M. Hoxby, Chicago: University of Chicago Press, pages 263-320.

Eckel, C. C., Grossman, P. J., and Johnston, R. M. (2005). An Experimental Test of the Crowding Out Hypothesis. Journal of Public Economics, 89(8):1543-1560. The Experimental Approaches to Public Economics.

Files, T. 1995 [machine-readable data files]/prepared by the Bureau of the Census - Washington, DC, 1996.

Geverdt, D. (2018). Education Demographic and Geographic Estimates Program (EDGE): School District Geographic Relationship Files User's Manual (NCES 2018-076). U.S. Department of Education. Washington, DC: National Center for Education Statistics. Retrieved [date] from http://nces.ed.gov/pubsearch.

Goldsmith-Pinkham, P., Sorkin, I., and Swift, H. (2020). Bartik instruments: What, when, why, and how. American Economic Review, 110(8):2586-2624.

Grosskopf, S., Hayes, K., Razzolini, L., and Taylor, L. (2020). Kids or Cash? Exploring Charter School Responses to Declining Government Revenues. Economic Inquiry, 58(2):802-818. 
Heutel, G. (2014). Crowding Out and Crowding In of Private Donations and Government Grants. Public Finance Review, 42(2):143-175.

Huck, S. and Rasul, I. (2011). Matched Fundraising: Evidence from a Natural Field Experiment. Journal of Public Economics, 95(5):351 - 362. Charitable Giving and Fundraising Special Issue.

Hungerman, D. M. (2005). Are Church and State Substitutes? Evidence from the 1996 Welfare Reform. Journal of Public Economics, 89(11):2245-2267.

Hungerman, D. M., Rinz, K., and Frymark, J. (2019). Beyond the Classroom: The Implications of School Vouchers for Church Finances. Review of Economics and Statistics, 101(4):588-601.

Jackson, C. K. (2018). Does School Spending Matter? The New Literature on an Old Question. Report, National Bureau of Economic Research, Inc.

Jackson, C. K., Johnson, R. C., and Persico, C. (2015). The Effects of School Spending on Educational and Economic Outcomes: Evidence from School Finance Reforms. The Quarterly Journal of Economics, 131(1):157-218.

Jackson, C. K., Wigger, C., and Xiong, H. (2018). Do School Spending Cuts Matter? Evidence from the Great Recession. National Bureau of Economic Research Working Paper Series, No. 24203.

Jones, D. B. (2015). Education's Gambling Problem: Earmarked Lottery Revenues and Charitable Donations to Education. Economic Inquiry, 53(2):906-921.

Krishnan, R., Yetman, M. H., and Yetman, R. J. (2006). Expense Misreporting in Nonprofit Organizations. The Accounting Review, 81(2):399-420.

Lee, K.-G. and Polachek, S. W. (2018). Do School Budgets Matter? The Effect of Budget Referenda on Student Dropout Rates. Education Economics, 26(2):129-144.

Mayo, J. (2021). Navigating the Notches: Charity Responses to Ratings. Working Paper, University of Michigan.

Meer, J. (2011). Brother, Can You Spare a Dime? Peer Pressure in Charitable Solicitation. Journal of Public Economics, 95(7):926 - 941.

Meer, J. (2014). Effects of the Price of Charitable Giving: Evidence from an Online Crowdfunding Platform. Journal of Economic Behavior \& Organization, 103:113-124.

Meer, J. (2017). Does Fundraising Create New Giving? Journal of Public Economics, 145:82-93.

Meer, J. and Rigbi, O. (2013). The Effects of Transactions Costs and Social Distance: Evidence from a Field Experiment. 14(1):271.

Meer, J. and Rosen, H. S. (2011). The ABCs of Charitable Solicitation. Journal of Public Economics, 95(5):363-371. Charitable Giving and Fundraising Special Issue.

Milton, R. T. (2017). Crowd-out of Private Contributions to Local Public Goods: Evidence from School Tax Referenda. Retrieved from: https://rossmilton.com/. 
Nelson, A. A. and Gazley, B. (2014). The Rise of School-Supporting Nonprofits. Education Finance and Policy, 9(4):541-566.

Okten, C. and Weisbrod, B. A. (2000). Determinants of Donations in Private Nonprofit Markets. Journal of Public Economics, 75(2):255-272.

Payne, A. A. (1998). Does the Government Crowd-out Private Donations? New Evidence from a Sample of Non-profit Firms. Journal of Public Economics, 69(3):323-345.

Ribar, D. C. and Wilhelm, M. O. (2002). Altruistic and Joy-of-Giving Motivations in Charitable Behavior. Journal of Political Economy, 110(2):425-457.

Roberts, R. D. (1984). A Positive Model of Private Charity and Public Transfers. Journal of Political Economy, 92(1):136-148.

Vesterlund, L. (2003). The Informational Value of Sequential Fundraising. Journal of Public Economics, 87(3):627-657.

Warr, P. G. (1982). Pareto Optimal Redistribution and Private Charity. Journal of Public Economics, 19(1):131-138.

Wash, R. (2013). The Value of Completing Crowdfunding Projects. Seventh International AAAI Conference on Weblogs and Social Media. 

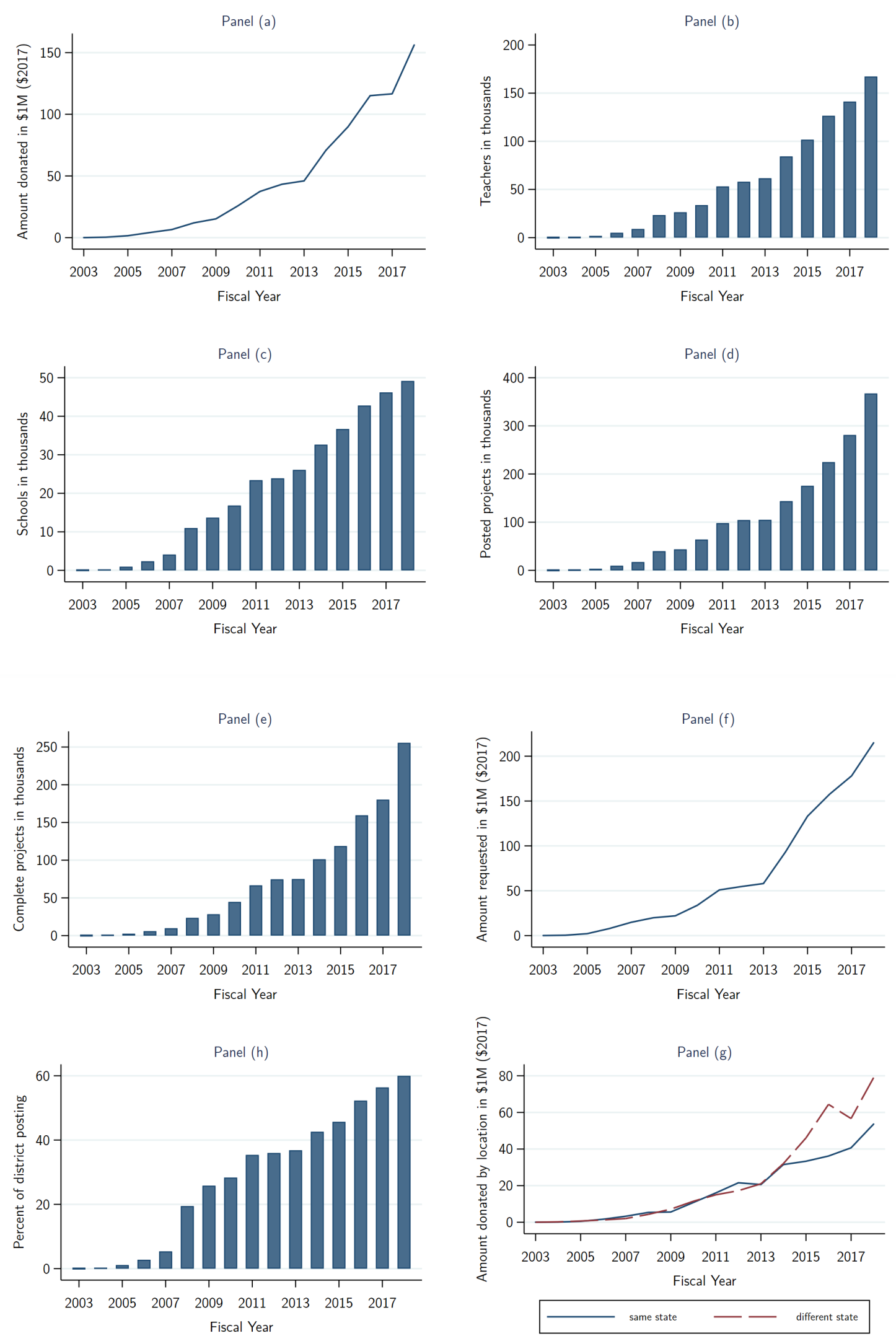

Figure 1: Some characteristics of the DonorsChoose.org data (2003-2018). 


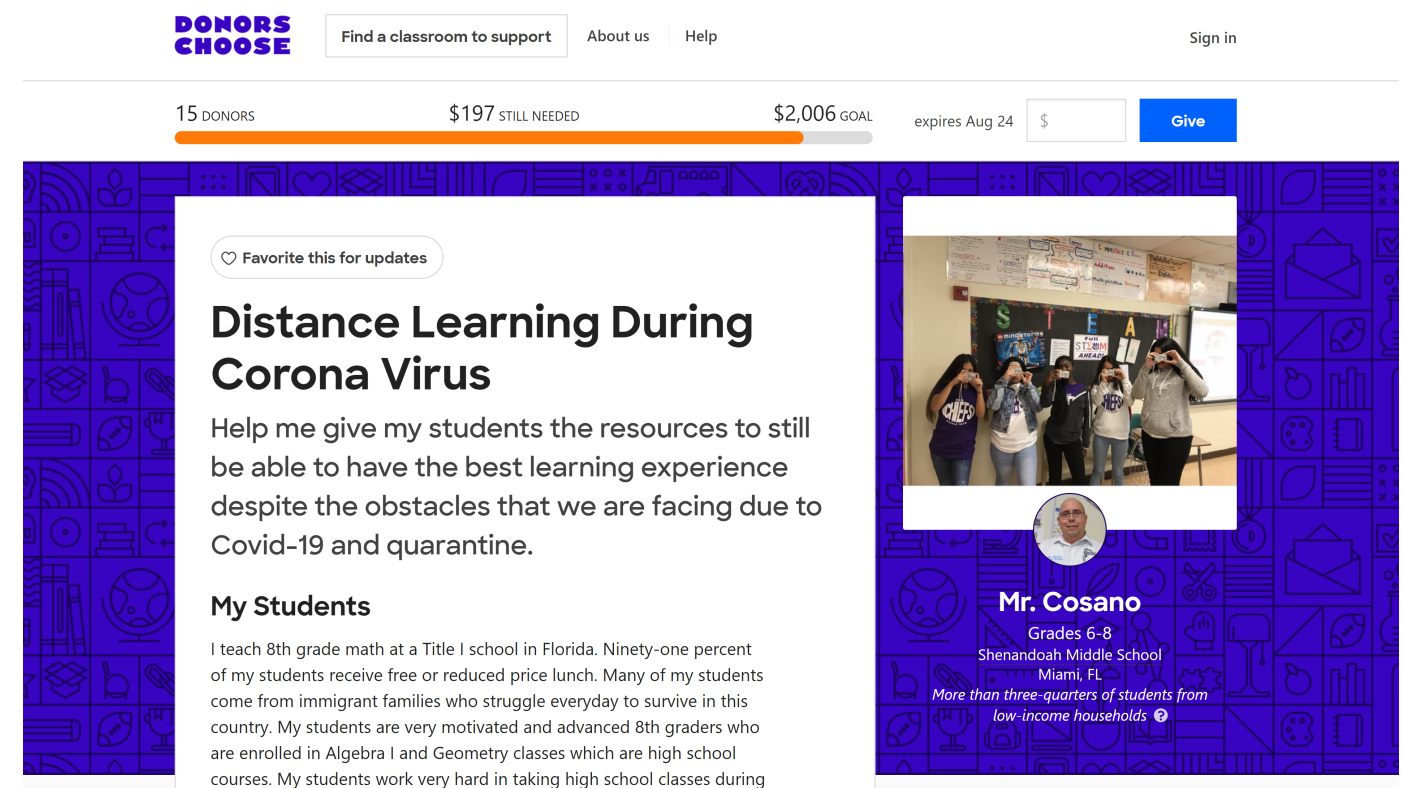

courses. My students work very hard in taking high school classes during

middle school and they strive to be the best every day.

\section{My Project}

The Coronavirus has shaken the world with new hardships for everyone. However, one of the most affected ones in the world would be the students who have to adapt to distance learning, something that has stunted their growth as well as deprived students of the traditional educational tools provided to them. Therefore, each teacher is also struggling with replacing their routine with a new way to give their students the best learning tools that they can use to still grow. Despite the unfortunate events caused by the Covid-19 outbreak, I am still determined to provide my students with the best educational experience possible.

These materials will help my students overcome the obstacles and hardships of distance learning and still have an amazing and interactive learning experience.

With the IXL program, my students will still be able to have their own personalized education program that will track their progress and aptitude in the lesson. Additionally, I will get accurate reports of each student's performance so I can adjust my lesson plans based on the results for each lesson. As a result, it would be almost as if $I$ am in the classroom with them, knowing which students are struggling in a particular subject so I can give each the time that they need to fully understand it.

\section{Where Your Donation Goes}

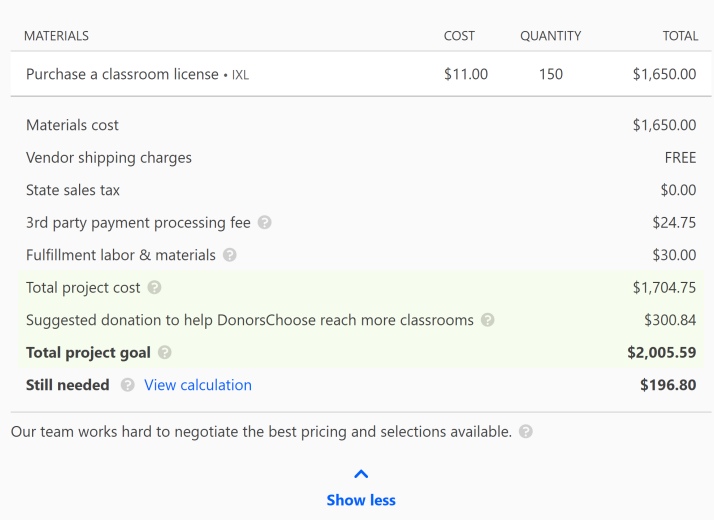

Figure 2: Sample DonorsChoose.org project posting. 


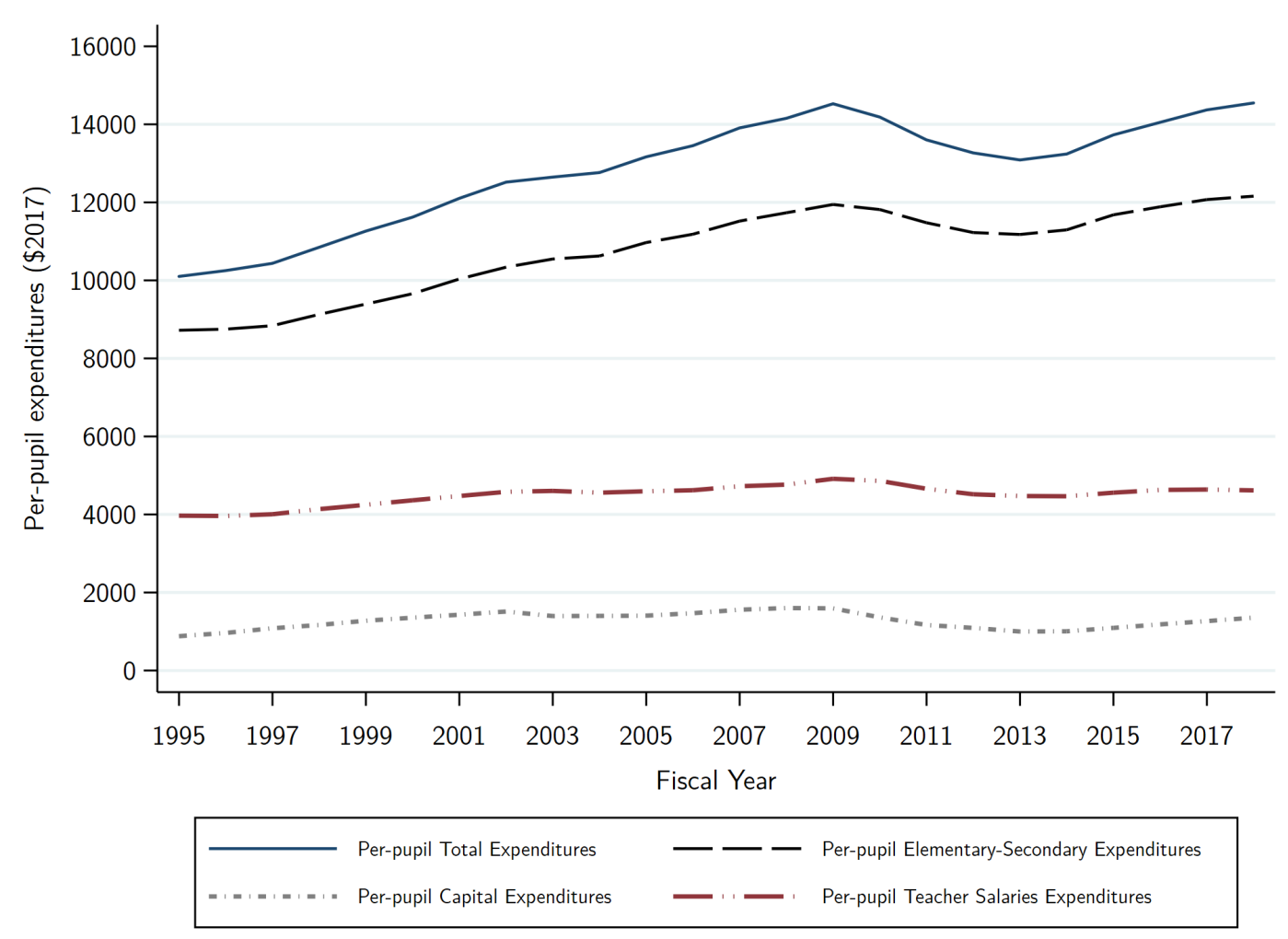

Figure 3: Per-pupil expenditures in 2017 dollars in school districts (1995-2018). 


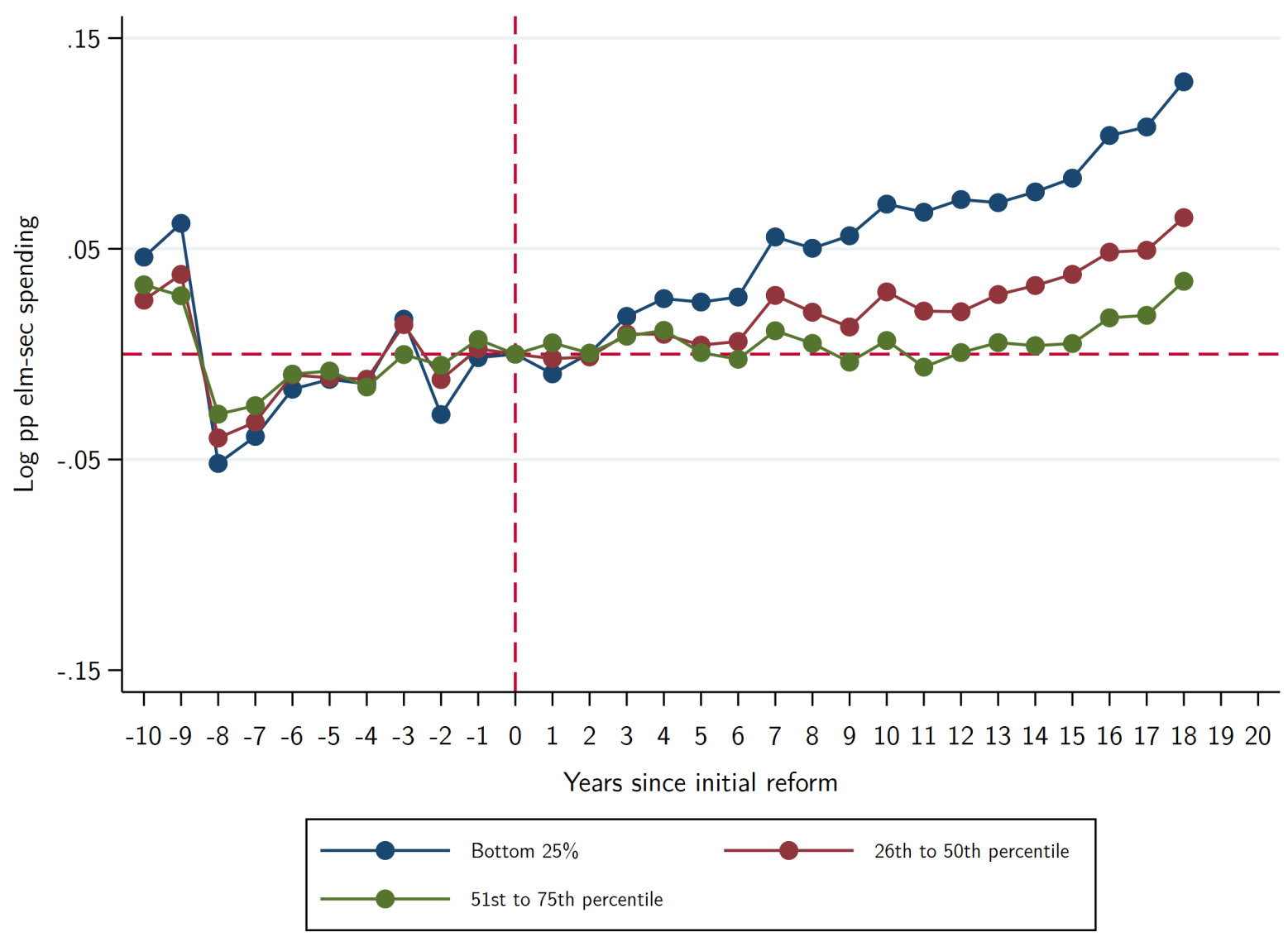

Figure 4: This figure shows an event study graph of the change in elementary-secondary school spending before and after court-mandated school finance reforms that occurred between 1995 and 2010. The event time indicators are interacted with the base year spending quartiles. Each series represent difference in the log of elementary-secondary school spending in the associate quartile compared to the omitted category (the highest-spending quartile) before and after the reforms. The regression includes year and district fixed effects. 
Table 1: Summary statistics

\begin{tabular}{|c|c|c|c|c|}
\hline $\begin{array}{l}\text { Panel A - unconditional } \\
\text { District Demographics }\end{array}$ & Mean & Std. Dev. & Median & Observations \\
\hline Fall Enrollment & 3255.40 & 14138.66 & 1013.00 & 352450 \\
\hline Total Teachers & 203.50 & 816.63 & 70.70 & 339836 \\
\hline Frac. White Enrollment & 0.73 & 0.29 & 0.86 & 349781 \\
\hline Frac. Black Enrollment & 0.10 & 0.21 & 0.01 & 347044 \\
\hline Frac. Hispanic Enrollment & 0.12 & 0.20 & 0.03 & 348900 \\
\hline Frac. Children In Poverty (Ages 5 to 17 ) & 0.16 & 0.10 & 0.15 & 274595 \\
\hline Any Project Posted & 0.22 & 0.41 & 0.00 & 352450 \\
\hline Any Donation Received & 0.20 & 0.40 & 0.00 & 352450 \\
\hline Number of Schools with Posted Projects & 0.90 & 6.79 & 0.00 & 352450 \\
\hline \multicolumn{5}{|l|}{ District Finance Data (\$2017) } \\
\hline Per-pupil Revenues & 13729.11 & 9261.62 & 11876.37 & 352450 \\
\hline Per-pupil Total Expenditures & 13719.36 & 9526.25 & 11767.35 & 352450 \\
\hline Per-pupil Elementary-Secondary Expenditures & 11505.96 & 6804.54 & 10108.61 & 352450 \\
\hline Per-pupil Capital Expenditures & 1211.11 & 2865.37 & 504.15 & 352450 \\
\hline Per-pupil Teacher Salaries Expenditures & 4588.61 & 2425.82 & 4172.03 & 352450 \\
\hline \multicolumn{5}{|l|}{ Panel B - conditional on any posting } \\
\hline Posting (\$2017) & Mean & Std. Dev. & Median & Observations \\
\hline Number of Teachers with Posted Projects & 11.10 & 63.05 & 2.00 & 76448 \\
\hline Number of Posted Projects & 20.57 & 137.42 & 3.00 & 76448 \\
\hline Amount Requested by Teachers & 12706.35 & 89676.53 & 2015.91 & 76448 \\
\hline \multicolumn{5}{|l|}{ Panel C - conditional on any donation } \\
\hline Donations $(\$ 2017)$ & Mean & Std. Dev. & Median & Observations \\
\hline Number of Complete Projects & 14.93 & 99.67 & 2.00 & 71728 \\
\hline Number of Donations & 117.21 & 1073.02 & 18.00 & 71728 \\
\hline Amount Donated & 9600.03 & 67922.86 & 1436.70 & 71728 \\
\hline Amount Donated within the Same State & 3557.14 & 32131.54 & 476.46 & 71728 \\
\hline Amount Donated by a Different State & 4714.58 & 32634.42 & 610.93 & 71728 \\
\hline
\end{tabular}


Table 2: Impact of per-pupil elementary-secondary expenditures on project postings

\begin{tabular}{|c|c|c|c|c|}
\hline & $(1)$ & $(2)$ & $(3)$ & $(4)$ \\
\hline Panel A: Extensive Margin & \multicolumn{4}{|c|}{ Any Posted Project } \\
\hline log pp elementary-secondary spending & $\begin{array}{c}-.063 \\
(.0075)\end{array}$ & $\begin{array}{l}-.047 \\
(.0081)\end{array}$ & $\begin{array}{l}-.053 \\
(.011)\end{array}$ & $\begin{array}{l}-.038 \\
(.013)\end{array}$ \\
\hline $\mathrm{N}$ & 352450 & 326871 & 265586 & 242367 \\
\hline Panel B: Intensive Margin & \multicolumn{4}{|c|}{ Log Requested Amount } \\
\hline log pp elementary-secondary spending & $\begin{array}{c}-.08 \\
(.049)\end{array}$ & $\begin{array}{l}-.072 \\
(.054)\end{array}$ & $\begin{array}{l}-.033 \\
(.083)\end{array}$ & $\begin{array}{l}-.042 \\
(.11)\end{array}$ \\
\hline $\mathrm{N}$ & 74789 & 61016 & 63899 & 49646 \\
\hline Panel C: Combined Effects & \multicolumn{4}{|c|}{ Panel A and B } \\
\hline log pp elementary-secondary spending & $\begin{array}{c}-.51 \\
(.059)\end{array}$ & $\begin{array}{l}-.38 \\
(.059)\end{array}$ & $\begin{array}{l}-.43 \\
(.093)\end{array}$ & $\begin{array}{c}-.31 \\
(.094)\end{array}$ \\
\hline $\mathrm{N}$ & 352450 & 326871 & 265586 & 242367 \\
\hline Year and District FE & Yes & Yes & Yes & Yes \\
\hline Controls & No & No & Yes & Yes \\
\hline State-Year FE & Yes & No & Yes & No \\
\hline County-Year FE & No & Yes & No & Yes \\
\hline
\end{tabular}

Standard errors in parentheses.

This table shows the impact of the per-pupil elementary-secondary expenditures on project postings. Expenditures and amount requested are in constant 2017 dollars. Panel A shows the results for the extensive margin (if a project is posted), while Panel B shows the intensive margins (amount requested). Panel $\mathrm{C}$ shows the marginal effect on the unconditional mean, combining Panels A and B. Columns 1 and 2 show the results with no controls, while columns 3 and 4 include share of children in poverty, enrollment shares by race, and log number of teachers. Columns 1 and 3 includes state-year fixed effects, while columns 2 and 4 include county-year fixed effects. 
Table 3: Impact of per-pupil elementary-secondary expenditures on donations

\begin{tabular}{|c|c|c|c|c|}
\hline & $(1)$ & $(2)$ & $(3)$ & $(4)$ \\
\hline Panel A: Extensive Margin & \multicolumn{4}{|c|}{ Any Giving } \\
\hline log pp elementary-secondary spending & $\begin{array}{c}-.058 \\
(.0075)\end{array}$ & $\begin{array}{c}-.041 \\
(.0081)\end{array}$ & $\begin{array}{l}-.044 \\
(.011)\end{array}$ & $\begin{array}{l}-.027 \\
(.013)\end{array}$ \\
\hline $\mathrm{N}$ & 352450 & 326871 & 265586 & 242367 \\
\hline Panel B: Intensive Margin & \multicolumn{4}{|c|}{ Log Amount Received } \\
\hline log pp elementary-secondary spending & $\begin{array}{l}-.046 \\
(.06)\end{array}$ & $\begin{array}{l}-.067 \\
(.065)\end{array}$ & $\begin{array}{l}.019 \\
(.10)\end{array}$ & $\begin{array}{c}-.0045 \\
(.13)\end{array}$ \\
\hline $\mathrm{N}$ & 69885 & 56362 & 59685 & 45704 \\
\hline Panel C: Combined Effects & \multicolumn{4}{|c|}{ Panel A and B } \\
\hline log pp elementary-secondary spending & $\begin{array}{c}-.43 \\
(.056)\end{array}$ & $\begin{array}{c}-.32 \\
(.056)\end{array}$ & $\begin{array}{c}-.32 \\
(.089)\end{array}$ & $\begin{array}{c}-.20 \\
(.091)\end{array}$ \\
\hline $\mathrm{N}$ & 352450 & 326871 & 265586 & 242367 \\
\hline Year and District FE & Yes & Yes & Yes & Yes \\
\hline Controls & No & No & Yes & Yes \\
\hline State-Year FE & Yes & No & Yes & No \\
\hline County-Year FE & No & Yes & No & Yes \\
\hline
\end{tabular}

Standard errors in parentheses.

This table shows the impact of the per-pupil elementary-secondary expenditures on donations. Expenditures and amount donated are in constant 2017 dollars. Panel A shows the results for the extensive margin (if a project receives any donation), while Panel $\mathrm{B}$ shows the intensive margins (amount donated). Panel $\mathrm{C}$ shows the marginal effect on the unconditional mean, combining Panels A and B. Columns 1 and 2 show the results with no controls, while columns 3 and 4 include share of children in poverty, enrollment shares by race, and log number of teachers. Columns 1 and 3 includes state-year fixed effects, while columns 2 and 4 include county-year fixed effects. 
Table 4: Impact of fundraising effort on donation

\begin{tabular}{lcccc}
\hline & $(1)$ & $(2)$ & $(3)$ & $(4)$ \\
& \multicolumn{4}{c}{ Log Amount Received } \\
\cline { 2 - 5 } Log amount requested & .92 & .91 & .92 & 0.90 \\
& $(.0042)$ & $(.0051)$ & $(.0046)$ & $(.006)$ \\
$\mathrm{N}$ & 71946 & 58494 & 59839 & 45864 \\
\hline Year and District FE & Yes & Yes & Yes & Yes \\
Controls & No & No & Yes & Yes \\
State-Year FE & Yes & No & Yes & No \\
County-Year FE & No & Yes & No & Yes \\
\hline
\end{tabular}

Standard errors in parentheses.

This table shows the impact of fundraising effort on donations for years 1995-2018. Donations are in constant 2017 dollars. Columns 1 and 2 show the results with no controls, while columns 3 and 4 include share of children in poverty, enrollment shares by race, and log number of teachers. Columns 1 and 3 includes state-year fixed effects, while columns 2 and 4 include county-year fixed effects. 
Table 5: Instrumented estimates of the effects of per-pupil elementary-secondary spending on project postings

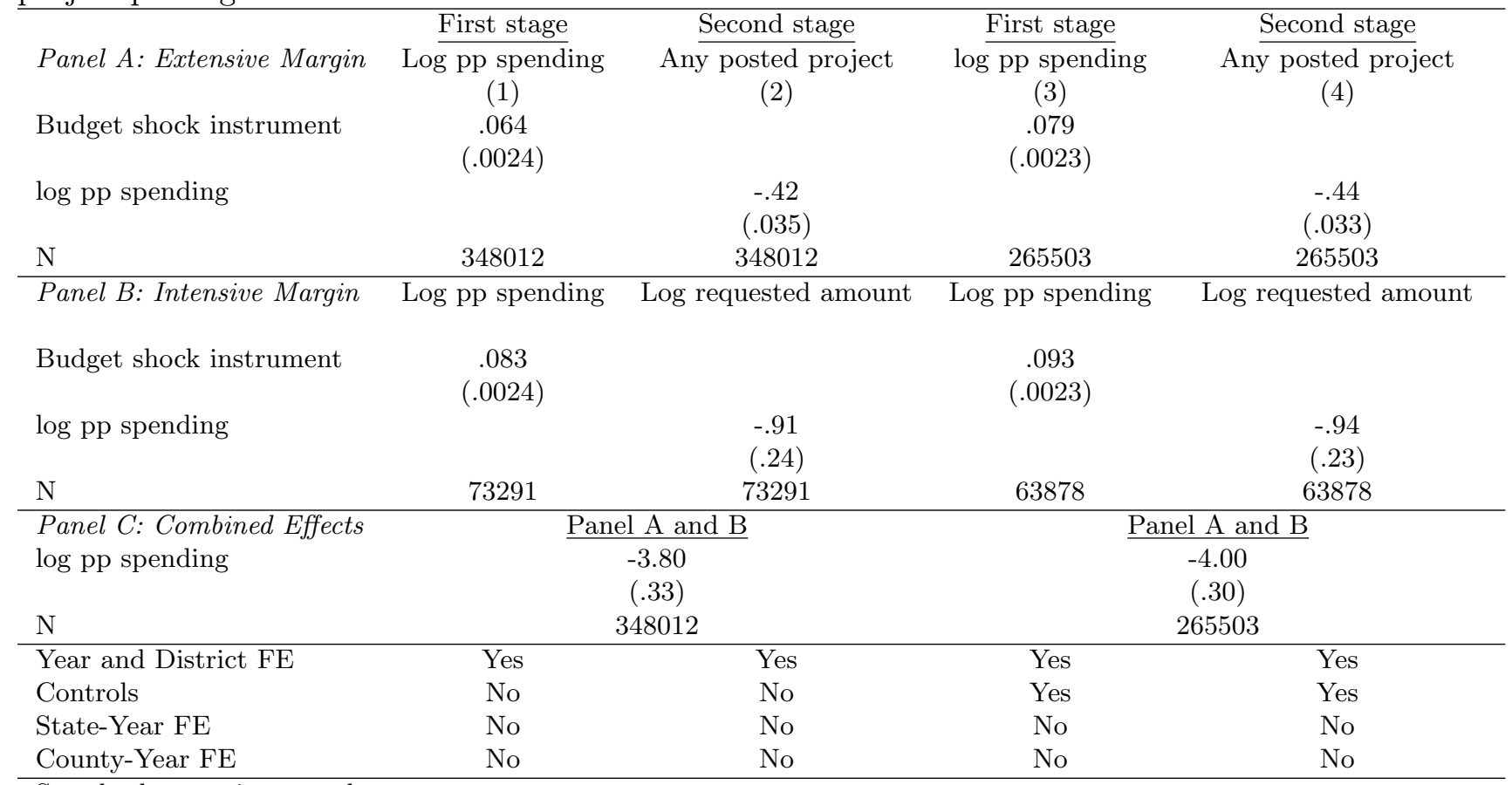

Standard errors in parentheses.

This table reports two-stage least squares estimates of the impact of the per-pupil elementary-secondary expenditures on project postings for years 1995-2018. In the first stage, we regress each district's log per-pupil elementary-secondary spending on constructed instruments as the budget shock and school finance reforms after 1995. The second stage regresses posting outcomes on predicated spending from the first stage. Expenditures and amount requested are in constant 2017 dollars. Panel A shows the results for the extensive margin (if a project is posted), while Panel B shows the intensive margin as the amount requested by teachers. Panel $\mathrm{C}$ shows the marginal effect on the unconditional mean, combining Panels A and B. Columns 1 and 2 show the results with no controls, while columns 3 and 4 include share of children in poverty, enrollment shares by race, and log number of teachers. All Columns include year fixed effects and district fixed effects. 
Table 6: Instrumented estimates of the effects of per-pupil elementary-secondary spending on donations

\begin{tabular}{lcccc} 
Panel A: Extensive Margin & Log pp spending & $\frac{\text { Second stage }}{\text { Any giving }}$ & First stage & $\frac{\text { Second stage }}{\text { Any giving }}$ \\
Budget shock instrument & $(1)$ & $(2)$ & $(3)$ & $(4)$ \\
log pp spending & .064 & & $(.0023)$ & -.41 \\
$\mathrm{~N}$ & $(.0024)$ & -.39 & & $(.033)$ \\
\hline
\end{tabular}

\begin{tabular}{|c|c|c|c|c|}
\hline Panel B: Intensive Margin & Log pp spending & Log amount received & Log pp spending & Log amount received \\
\hline Budget shock instrument & $\begin{array}{c}.084 \\
(.0024)\end{array}$ & & $\begin{array}{c}.094 \\
(.0024)\end{array}$ & \\
\hline log pp spending & & $\begin{array}{l}-1.60 \\
(.30)\end{array}$ & & $\begin{array}{r}-1.50 \\
(.29)\end{array}$ \\
\hline $\mathrm{N}$ & 68469 & 68469 & 59666 & 59666 \\
\hline Panel C: Combined Effects & \multicolumn{2}{|c|}{ Panel $A$ and $B$} & \multicolumn{2}{|c|}{ Panel $\mathrm{A}$ and $\mathrm{B}$} \\
\hline log pp spending & \multicolumn{2}{|c|}{$\begin{array}{l}-3.40 \\
(.31)\end{array}$} & \multicolumn{2}{|c|}{$\begin{array}{c}-3.60 \\
(.29)\end{array}$} \\
\hline $\mathrm{N}$ & \multicolumn{2}{|c|}{348012} & \multicolumn{2}{|c|}{265503} \\
\hline Year and District FE & Yes & Yes & Yes & Yes \\
\hline Controls & No & No & Yes & Yes \\
\hline State-Year FE & No & No & No & No \\
\hline County-Year FE & No & No & No & No \\
\hline
\end{tabular}

Standard errors in parentheses.

This table reports two-stage least squares estimates of the impact of the per-pupil elementary-secondary expenditures on donations for years 1995-2018. In the first stage, we regress each district's log per-pupil elementary-secondary spending on constructed instruments as the budget shock and school finance reforms after 1995. The second stage regresses donations on predicated spending from the first stage. Expenditures and amount donated are in constant 2017 dollars. Panel A shows the results for the extensive margin (if a project receives any donation), while Panel B shows the intensive margin as the amount donated. Panel $\mathrm{C}$ shows the marginal effect on the unconditional mean, combining Panels $\mathrm{A}$ and B. Columns 1 and 2 show the results with no controls, while columns 3 and 4 include share of children in poverty, enrollment shares by race, and log number of teachers. All Columns include year fixed effects and district fixed effects. 
Table 7: Instrumented estimates of the effects of fundraising effort on donation

\begin{tabular}{|c|c|c|c|c|}
\hline & Log amount requested & $\frac{\text { Second stage }}{\log }$ & Log amount requested & $\log \frac{\text { Second stage }}{\text { amount donated }}$ \\
\hline Log Amount of Neighbors' & -.045 & & -.0083 & \\
\hline Requests in $\mathrm{t}-1$ & $(.0046)$ & & $(.0068)$ & \\
\hline Log Number of Neighbors' & .16 & & -.051 & \\
\hline Posted Projects in t-1 & $(.012)$ & & $(.017)$ & \\
\hline Log amount requested & & 1.00 & & 1.20 \\
\hline & & $(.058)$ & & $(.16)$ \\
\hline $\mathrm{N}$ & 58465 & 58465 & 44540 & 44540 \\
\hline Year and District FE & Yes & Yes & Yes & Yes \\
\hline Controls & Yes & Yes & Yes & Yes \\
\hline State-Year FE & Yes & Yes & No & No \\
\hline County-Year FE & No & No & Yes & Yes \\
\hline
\end{tabular}

Standard errors in parentheses.

This table shows the impact of amount requested on amount donated for years 1995-2018. It shows the 2SLS estimates using instruments as amount requested and number of posted project by neighboring districts at t- 1 . Columns 1 and 2 include state-by-year fixed effects, while the other columns include county-by-year fixed effects Donation and request amounts are in constant 2017 dollars. All the columns include the share of children in poverty, enrollment shares by race, and log number of teachers. 